KYIV-MOHYLA

HUMANITIES JOURNAL

KYIV-MOHYLA SCHOLARLY PEER-REVIEWED JOURNALS

The Reconstruction of Christian Theodicy in Taras Shevchenko's Poetry

Author(s): Olha Bihun

Source: Kyiv-Mohyla Humanities Journal 6 (2019):161-176

Published by: National University of Kyiv-Mohyla Academy

http://kmhj.ukma.edu.ua/ 


\title{
The Reconstruction of Christian Theodicy in Taras Shevchenko's Poetry
}

\author{
Olha Bihun
}

Vasyl Stefanyk Precarpathian National University, Department of French Philology

\begin{abstract}
This article focuses on the role of Christian theodicy in Taras Shevchenko's works. With a biography marked by trauma and suffering, it is no wonder that Shevchenko orients his poetic worldview in search of understanding the nature of evil and human suffering. Operating through a Christological model, Shevchenko arrives at a poetics based on theodicy, as a means of understanding suffering in the world. He analyses the problem of evil associated with the phenomenology of suffering within the framework of religious ethics. The works of the early period emphasize "truth and revenge," retribution, and physical punishment over the "malicious" in the spirit of Old Testament dogma. The period of Shevchenko's exile and subsequent works is characterized by changes in moods. The theodicy of Shevchenko's works reveals the signs of Christodicy. Shevchenko's concept of "suffering" is theologically based, as he believes that suffering is the key to conversion to faith.
\end{abstract}

Key Words: theodicy, Christianity, suffering, evil, anthropology, Taras Shevchenko.

\section{Introduction}

Within the anthropocentric paradigm of suffering is revealed through the notions "good" and "evil," which are the central motives of human activity. The philosophical side of the notion "evil" embraces three aspects: the logical (a good God would destroy evil, though evil is impossible to destroy, that is why there is no good and almighty God), ${ }_{1}$ evident (evil takes terrific forms, innocent people suffer, and that is why it is impossible to explain God's will), ${ }^{2}$ and existential (having comprehended evil, a person loses faith). ${ }^{3}$ Religious considerations about the existence of evil are estimated through the consciousness of a believer who is suffering.

The problem of spiritual-religious tradition in the works of Taras Shevchenko (1814-1961), Ukraine's iconic nineteenth-century romantic poet, is of utmost importance. Christianity appealed to Shevchenko, first of all, due to humanity virtues, idealization of the commandments of brotherhood, love, peace, and its vision of social justice for

1 Daniel Howard-Snyder, The Evidential Argument from Evil (Bloomington: Indiana University Press, 1996), 148-49.

2 Howard-Snyder, The Evidential Argument, 151. 
the humble and the poor. However, in his religious-philosophical searches, Shevchenko often hesitated between rational reflections, which made him doubt the truthfulness of Christian dogma and the existence of God, and emotional-sensitive waves of "the heart" that inclined him to the faith. According to Shevchenko, it was God who was both blind and indifferent to people's suffering and the "all-good."

Taking into account various interpretations of the theodicy question in Ukrainian and international Shevchenko studies, ${ }^{4}$ this article applies it as a philosophical and anthropological disciplinary framework for a consideration of the phenomenon of "evil" (based on the Christian exegetics of the fathers of Church and modern theology) and the reconstruction of Christian theodicy in Taras Shevchenko's writings.

\section{Theodicy in the Bible and Patristic Studies: Shevchenko's Reception}

It is known that the main source of Christian theodicy is the Bible. Both the Old Testament and the New Testament tell of the imperfection of the world and the existence of evil in it. A human being of the Old Testament believed in the absolute justness of a God who viewed evil as a payment for sins. The problem of theodicy is explained from the position of a full trust in God's deeds (Job, for instance) without any theoretical assumptions. In the New Testament the notion of "evil" is not explained on the metaphysical level, instead it provides directives on how to live in a world where evil dominates and how to fight it. The problem of the existence of a good God and evil was divided among the Fathers of the Church into three types: Augustinian theodicy, Irenaean theodicy, and process theodicy. The basis of Augustinian theodicy is the conception of identifying God and the world created by Him exclusively with good, artistic potential, and mercy. Evil, according to Augustine, is not a substance, matter, or an item. It is the negation, the loss or damage of things. "Soul making theodicy," according to John Hick, prevails in the works of Saint Irenaeus of Lyons, a bishop of the early Christian Church. ${ }^{5}$ This theodicy does not research the origin of evil, but

See Dmytro Buchynskyi, Khrystyiansko-filosofska dumka Tarasa H. Shevchenka [Taras

Shevchenko's Christian-Philosophical Conception] (Madrid; London: Soiuz ukraintsiv u Velykii Brytanii, 1962); Ivan Dziuba, "Boh. Relihiia. Tserkva u tvorchosti Tarasa Shevchenka [God. Religion. Church in Taras Shevchenko's Works]," Taras Shevchenko i narodna kultura 1 (2004): 150-69; Włodzimierz Mokry, Literatura i myśl filozoficzno-religïna ukraińskiego romantyzmu: Szewczenko, Kostomarow, Szaszkiewicz (Kraków: Uniwersytet Jagielloński, 1996); Yevhen Nakhlik, Dolia —Los — Sudba: Shevchenko i polski ta rosiiski romantyky [Fate — Los —Destiny: Taras Shevchenko and Polish and Russian Romantics] (Lviv: Svit, 2003); Dmytro Stepovyk, Nasliduiuchy Khrysta: viruiuchyi u Boha Taras Shevchenko [Following the Example of Christ: Believer in God Taras Shevchenko] (Kyiv: Vydavnytstvo im. Oleny Telihy, 2013); Vasyl Yaremenko, "Liudei i ... ne prokliav!' (Do problemy Shevchenkovoho traktuvannia teodytsei) ['The People but ... He Didn't Damn!' (On the Problem of Shevchenko's Interpretation of Evil)]," Kyivska starovyna 2 (2005): 108-17. 
emphasizes the evolutionary aspect of the problem. Evil is treated not as the "damage" or "decline" of a perfect primeval thing, but as an obligatory stage of the transformation of an undeveloped person to a developed one. Process theodicy argues that God does not have a monopoly of power, which is why people, having the right of free will, may reject God's plan; in other words they have the right to commit evil.

For the Byzantine model of Christianity, whose tradition formed the world view of Taras Shevchenko, the notions of "evil" and theodicy are based on the notions of "sin" and "suffering," among which sin is an active type of evil and suffering is passive. In the philosophical treatises of John Chrysostom, who was regarded by the Old East Slavic Christian tradition as a teacher of morality and faith, priority is assigned to the doctrine in terms of virtues based on the principles of Christian morality. Virtues, according to the theologian, oppose drawbacks and, thus, construct two poles in the system of personal values. Original sin, having disintegrated human nature, breaks the state of "a complete hierarchy." John Chrysostom regards the problem of the depravity of a person as "inveteracy in sin," meaning that drawbacks are stages in the process of the erroneous personal and value orientation that cause the violation of ontological and axiological foundations of life principles and, as a consequence, usher in the loss of self-value and an ethical sense of existence. The specificity of free direction in personal orientation in the treatises of John Chrysostom is based on the notion of consciousness, which contains the aspects of self-restraint as an ethical necessity, and responsibility as the principle of relation to life. ${ }^{6}$

The Byzantine spiritual and ethical heritage became the cornerstone for the development of the theological thought of the Old Kyivan scribes: Metropolitan Ilarion, Danyil Zatochnyk, Klyment Smoliatych, Kyrylo Turovskyi and others. Great attention is paid to the issue of sin in the Kyievo-Pecherskyi Pateryk (Kyivan Cave Patericon). The main prerequisite of achieving sanctity is overcoming the physical and sinful sides of oneself. As a result, the fight is transferred from the outer world into the inner one. Legends from this period show numerous examples illustrating the struggle between these aspects of a human life: the monk Erasmus overcomes regrets about his lost wealth ("Slovo 21"), Aretas fights stinginess ("Slovo 22"), and the soul of Fedor hesitates between the ideals of ascetics and the secular desire to live a free and full life ("Slovo 33").7

In the Skazanie o chernorizchem chine (Legend of the Monk Rank), Kyrylo Turovskyi argues that "a wise sin" (conscious sin) is not just a mere sin, but a real evil. In particular, the author quotes Peter the Apostle: "It would have been better for them not to have known the way of righteousness than to know it and turn their backs on the holy commandment that was passed to them" (2 Pt. 2:21). This legend does not only set high ethical standards in the works of Kyrylo Turovskyi, it is also an example for personal moral patterns, which introduces the notion of the ideal moral life. ${ }^{8}$

6 Ioann Zlatoust, Polnoe sobranie tvoreniiv 12 tomakh [Complete Works in 12 Volumes], vol. 3

(Pochaev: Sviato-Uspenskaia Pochaevskaia Lavra, 2005), 81-83.

7 Dmytro Abramovych, Kyievo-Pecherskyi Pateryk [Kyivan Cave Patericon] (Kyiv: Chas, 1991).

8 Vilen Horskyi, Narysy z istorii filosofskoi kultury Kyivskoi Rusi (seredyna XII-seredyna XIII stolit) [Essays on the Philosophical Culture of Kyivan Rus (Middle of the 12th to the Middle of the 
The sense of life for Turovskyi consists of action. The absence of action represents death for a person. In the "Slovo o rozslablennom" (The Parable on the Limp Man) "a weak person," who has been in bed for 38 years argues that, in fact, he is "an unburied dead person": "I feel both dead and alive, because I try to live, but can't surpass my immovability." ${ }^{9}$ Beliefs of this kind regularly appear in the works of Shevchenko:

Don't let me walk around asleep,

A dead heart in my breast,

And roll about, a rotten log,

A hindrance to the rest ("The Days Go By").10

The poet asserts that the culmination of an inactive type of life is the suffering of a person deprived of self-realization:

My bed is dirty

Pool, there I lie, a log, and rot.

And when I rot away, then what?..

Upon this plundered earth, its certain,

No vestige will remain of me... ("At Times I Hang My Head in Sorrow"). ${ }^{11}$

So, the notion of $\sin$, accentuated more on the question of an inner spiritual fight than on its outer manifestations in the works of Shevchenko relates to the notions of Bible dogmata and to the principles of the Fathers of the Church of the Byzantine tradition. Namely, Basil the Great stated:

Evil is not a living being, but the state of the soul opposite to virtue and it comes through deviation from good. That's why we should not look for evil outside, not imagine the existence of a primary evil nature, let everyone acknowledge himself as the cause of a malicious nature. ${ }^{12}$

13th Centuries)] (Kyiv: Naukova dumka, 1994), 56.

9 Kirill Turovskii, "Slovo o rozslablennom [The Parable on the Limp Man]," in Trudy Otdela Drevnerusskoi Literatury v 62 tomakh, vol. 4 (Moscow; Leningrad: Izdatelstvo Akademii Nauk USSR, 1959), 68. Translation from the Church Slavic by Olha Bihun.

10 Taras Shevchenko, Selected Works, Poetry and Prose, trans. Irina Zheleznova (Moscow: Progress Publishers, 1979), 303 .

11 Shevchenko, Selected Works, 253.

12 Vasylii Velykyi, Moralno-asketychni tvory [Ethic and Ascetic Works] (Lviv: Svichado, 2006), 212. 


\section{Christian Notions of Evil, Sin, and Suffering}

In the baroque era the notion of sin and punishment is conveyed by means of religious writing, so artists affirmed Christian morality in their texts irrespective of genre peculiarities.

A typical baroque motive of life's futility is firmly related to the truth about inevitable payment for sins in case of an unjust mode of life. The whole life philosophy of a baroque writer and his corresponding attitude to the world are determined by Christian endeavors, meaning to suffer and to rely on God's justice. ${ }^{13}$

Moral teachings of that time developed not in philosophical, but in theological and church discourses. In pamphlets and sermons that were given during various celebrations, we can find a list of references related to the good shepherd, perfect ruler, brave warrior, and to any faithful Christian. But this general set of virtues is rather a rhetorical formula than a modeled reality in accordance with certain moral and ethical prescriptions. Baroque writers adjusted their sins according to the dogmas of theology. So, the description of sins according to ecclesiastic classification forms the basis for Ioanykii Haliatovskyi's book Hrikhy rozmaiti (Sins Diverse); the poetic writings of Kyrylo Tranquillon-Stavrovetskyi, Epifanii Slavynetskyi; and the sermons of Antin Radylovskyi, Stefan Yavorskyi and others.

At that time the book Myr z Bohom choloviku (Peace with God for Man) by Inokentii Gizel was popular in Ukraine. Volodymyr Perets regards this book not only as the generalization of theological ideas about sin, but also as a practical manual for the comprehension of moral principles of the community at the time. ${ }^{14}$ The main principles of the ethical treatise continued to be topical for a long period of time, including in Shevchenko's times, which is why it is important in the present research to compare the notion of "sin" in Gizel's treatise with that in Shevchenko's works.

Despite the general principles of the reasons for evil, sin, and the reasons for its expiation, the peculiarity of Gizel's Myr is the creation of a scale of sins for every profession, every age, and even different family status in Ukrainian society of the time. The author describes sins of the clergy, from archbishops to simple monks, of the married, engaged and widowed, and of the defenders of "peasants" - custodians, notaries, and other "representatives" of poor people. Gizel does not avoid the description of authorities' sins - those of monarchs, wealthy people, judges, customs

13 Larysa Dovha, “Sotsialna utopiia Inokentiia Gizelia [Inokentii Gizel's Social Utopia]," in

Ukraina XVII stolittia: suspilstvo, filosofiia, kultura, ed. Larysa Dovha and Nataliia Yakovenko

(Kyiv: Krytyka, 2005), 227.

14 Vladimir Perets, Issledovaniia i materialy po istorii ukrainskoi literatury XVI-XVIII vekov [Researches and Materials in the Ukrainian Literature of the 16th-18th Centuries] (Moscow, Leningrad: Izdatelstvo Akademii nauk USSR, 1962), 185-86. 
officers, doctors, painters, craftsmen, teachers and students, innkeepers, etc. In the above enumerated professional list of moral and ethical merits, Gizel emphasizes the sins of "merchants," commenting that merchants are guilty of slyness, insidiousness, mendacity, and other faults accentuating the question of material enrichment. ${ }^{15}$

Gizel's remark may provide a hint for understanding a series of sepias entitled Prytcha pro bludnoho syna (The Parable of the Prodigal Son). Researchers of Shevchenko's art heritage gave different explanations concerning the desire of the artist to depict "the son of a merchant" in a painting. The poet writes in his Shchodennyk (Diary):

Our young middle class is like an idle student, who stopped studying syllables and cannot continue without a teacher's directions, he cannot overstep that incoherent letter horror. The drawbacks and faults of our upper class should not be paid attention to. First of all, due to its small numbers, second of all, due to chronic moral disorders, but chronic diseases are cured, if cured at all, by means of heroic deeds, the means of satire are powerless here. Is our small higher society of any importance in the nationality aspect? I believe it is not. And the middle class is a large, unfortunately only partially literate mass, and that is half the people, that is the heart of our nation, it does not need a tale about the prodigal son, instead, it needs noble, refined, and apt satire. I would be the happiest man in the world if I succeeded in that frank, sincerely planned idea, that unconscious scoundrel, my prodigal son. ${ }^{16}$

It seems that Shevchenko's idea originates from the seeds of his religious and philosophical interpretations about the path of a man to God based on the Bible and moral-didactic works of Ukrainian writers of the 17 th century.

Leonid Pliushch claims that:

the analysis of the texts, created in prison and after it, testifies to Shevchenko's thorough knowledge of the writings of the Holy Fathers and shows his own comprehension of the ethical and theological issues of theodicy and anthropodicy, of the psychology and anthropology of a person. Not without a reason the images of "the prodigal son" and the just person become major in his prose and appear in his paintings. In prison Shevchenko is looking for

Inokentii Gizel, Vybrani tvoryv 3 tomakh [Selected Works in 3 Volumes], vol. 1 (Kyiv: Svichado, 2009), 122-23.

16 Taras Shevchenko, Povne zibrannia tvoriv u 12 tomakh [Complete Works in 12 Volumes], vol. 5 (Kyiv: Naukova dumka, 2003), 29. Here and subsequently, unless indicated otherwise, translations from the Russian are by Olha Bihun. 
religious and ethical reasons and the origin of the eternal circle of evil, sin, hell in the paradise created by God. ${ }^{17}$

In Shevchenko's works we see the inclination to a kind of normalization of sins according to Gizel's scheme, though the poet colors his scale with a bitter irony:

Each man on earth has his own fate,

Each one his highway wide:

This one builds up, that one lays waste,

And that casts greedy eyes

O'er all the globe, to find somewhere

A land not yet enslaved,

Which he could conquer and then bear

With him into the grave.

This fellow in his neighbour's home

His host cleans out at cards,

While that one in a corner hones

A blade for his brother's heart.

Then there's the sober citizen,

The worthy, pious kind,

Who'll creep up like a cat and then

Bide patiently his time

Until with hardship you're beset,

And then he'll pounce! — Don't plead:

The tears your wife and children shed

Won't save you from his teeth ("A Dream").18

Regardless of social ranges, the poet verbalizes his dominant message, his main idea, which is relevant to the commandments of the New Testament: "In this world everyone — / The princes, and the beggar, too, — / They all are Adam's sons" ("A Dream"). ${ }^{19}$ Despite the dominant tone of summarizing general Christian values, Shevchenko's works also contain aspects of social differentiation. Though in his accusatory poems, the poet is sorry neither for Cossack hetmans, nor "hungry" landowners "with silver and gold," nor officials, trying "to skin both fathers and brothers," nor "pigheaded" poetasters, nor military lickspittles.

The estimation of the sinful "deeds" of rich people, described in the book by Inokentii Gizel, has direct and indirect parallels with Shevchenko's works. Thus, "real Christians," represented as authorities, are worried only about their own enrichment, acquired by

\footnotetext{
17 Leonid Pliushch, Ekzod Tarasa Shevchenka [Taras Shevchenko's Exodus] (Kyiv: Fakt, 2001), 151.

18 Shevchenko, Selected Works, 126.

19 Shevchenko, Selected Works, 127.
} 
widows' tears alone they could

Be drowned together with their seed!

The sweetheart's tears, in secret shed!

Unappeasable mothers' tears!

The heavy tears of fathers hoary! ("The Caucuses"). ${ }^{20}$

They are brutal in the treatment of simple people: "trade or sell, and sometimes lose in cards as well, live souls." ${ }^{21}$ And they neglect the Christian commandment of love for your neighbor "not for your brother's soul you care, but for your brother's hide!"22 It is easy to notice that the reason for evil in Shevchenko's convictions is primarily of a social character with the specific load of sin on the upper class. But that is only one of the extensions of theodicy in the artist's works concerning the social order of human society. Hereinafter we shall touch upon aspects of the psychological and existential exhibition and correlation of the author's interpretation of social and individual evil.

\section{Taras Shevchenko's Philosophical Path}

Ukrainian philosophical thought adheres to the belief that the works of the poet do not form a system, like theology or academic philosophy do. It is believed that Shevchenko created a "philosophical path," 23 not a system characterized by the absence of oblique forms or ceremonies; this is a complex of notions, moving constantly in search of the truth between opposite statements, based on the definitions of "immaculate truths," constant laws, and values. In a similar structure, the thoughts of the poet seem like the apophatic path of the perception of absolute truth by means of negation. "The apophatic method, like the religion of path generally, like path philosophy (life philosophy) is typical of the mystical perception of God and of personal communication with the upper spiritual world, with the manifestation of one's inner world." ${ }^{24}$ Such a manifestation "of communication with the higher spiritual world of the unseen" 25 for Shevchenko was his creative work, which was, according to George Grabowicz, "mostly autobiographical, that his poetry, as well as prose, is a constant self-projection." 26 A reconsideration of one's spiritual and biographical experience is the code for Shevchenko's works. Thus, the modus of "suffering” in Shevchenko's works appears in

20 Shevchenko, Selected Works, 170.

21 Shevchenko, Selected Works, 172.

22 Shevchenko, Selected Works, 172.

23 Tetiana Honcharuk, "Postat Tarasa Shevchenka u filosofskykh intentsiiakh Oleksandra

Kulchytskoho [The Figure of Taras Shevchenko in the Philosophical Intentions of Oleksandr

Kulchytskyi]," Mandrivets 6 (2008): 81.

24 Karl R. Popper, The Open Society and its Enemies, vol. 1 (London: Routledge, 1962).

25 Popper, The Open Society, 27.

26 George Grabowicz, Shevchenko, yakoho ne znaiemo [Shevchenko That is Unknown] (Kyiv:

Krytyka, 200o), 62. 
the process of the contemplation of the reasons for his dramatic fate, leading the poet to speculate on the reasons for earthly evil and human suffering.

As we know, the life of Shevchenko from his birth and to his death was filled with tragic events and suffering, which is why notes of sadness are present not only in the poetry of the exile period, but also in the works of his earlier period. Shevchenko's life is marked by tragedy: he lived for 47 years, 24 of which he spent as a serf, for 10 years he was a soldier in exile, for 3.5 years he was under police surveillance, and only for 9 years was Shevchenko a free man. After everything he had gone through his soul must not have been "free" from suffering, doubts, sadness, and sorrow. The poet was born and grew up in the authentic Ukrainian rural world where the Christian world-view and emotional foundation of the Ukrainian ethnos was based on love for God, one's neighbor, and for real things. Shevchenko's life problems appeared later due to the spiritual maturation of the poet and an impressive egregious contrast of Christian ideals and ugly reality (as he mentions in his poem describing his childhood "in heaven I saw hell"). Horror and sorrow are especially revealed in the exile poetry, which Grabowicz considers to be one long, though interrupted, monologue-confession that depicts both his physical and his mental state, the feeling of his fate, and his destiny. Grabowicz writes:

The characteristic feature is that every part of his hideable Mala knyzhka (Small Book) begins with contemplation on this theme and such works as "Chy to nedolia, chy nevolia" (Neither Fate, nor Freedom), "A numo znovu virshuvat" (Let's Write Poems), "O dumy moi! O slavo zlaia!” (Oh, my Thoughts! Oh, Angry Fame!), "Khiba samomu napysat" (Unless I Write Myself) become the summit of glory and a very modern example of the artist's suffering and selfsacrifice. $^{27}$

In later works Shevchenko draws the path of the theodicy, from the call for physical confrontation of evil by means of revenge ("Haidamaky" (The Haidamaks), "Tarasova nich" (The Night of Taras), "Kholodnyi Yar" (The Cold Ravine)), according to the Old Testament commandment of "eye for eye, tit for tat" to the assertion of the positive program of New Testament kindness ("Neofity" (The Neophytes), "Mariia" (Maria), "Buvaly voiny i viiskovi chvary" (There Were Wars And Military Battles)). Volodymyr Pakharenko remarks that in Shevchenko's late works the motif of revenge is not considered to even be an option. That is due to the fact that the main motif of Shevchenko's work of the last years became his firm faith that only the word of the truth of Christ will free Ukraine and the whole of mankind from evil. Pakharenko suggests that Shevchenko's three versions of "Molytva" (Prayer) demonstrate spiritual and physical imperatives "so that the reader could open, follow and comprehend one's own path to the truth of Christ." 28

27 Grabowicz, Shevchenko, yakoho ne znaiemo, 109

28 Volodymyr Pakharenko, “'Oi try shliakhy shyrokii...' (Pro Shevchenkove bachennia borotby zi zlom) ['Oh Three Roads Wide...' (About Shevchenko's Vision of the Battle Against Evil)]," 


\section{Taras Shevchenko's Christian Perspectives}

Generally, suffering provokes pain, and if one analyzes the poetry of Shevchenko from the point of view of the sensual palette, emotional memory will turn out to be the only form of memory in the works of the Ukrainian artist. Tetiana Bovsunivska states:

Shevchenko's constant addressing of the notion of incurable pain may be called mnemonic suffering in Shevchenko's poetry, as in an amplified reading of this notion in his works reveals a gradation of pain as the existential state of his soul.29

Yurii Barabash,, ${ }^{30}$ Antonina Hurbanska, ${ }^{31}$ Oksana Zabuzhko, ${ }^{32}$ Tetiana Meizerska ${ }^{33}$ and others mark existential issues as the immanent constituent of Shevchenko's artistic thinking. Yevhen Nakhlik remarks that:

both in exile and upon his return, Shevchenko was not only in the role of the prophet and apostle, but he also created another model for a poet - that of the existential lyricist, depressed by his mission of prophet and apostle, which was given to him not only of his own free will, but also by chance, and by his romantic and exalted fellow countrymen, despite his inner passionate desire to realize his natural potential as a private person... ${ }^{34}$

The doubts in the expediency of the chosen civil mission and miserable private life led to inner conflict and to suffering, without the perspective of reconciliation.

In Shevchenko's poetry evil is closely connected with suffering. The poet did not come to this connection rationally, rather, he tried to give his personal vision of this problem in the process of "experiencing the world." Yevhen Nakhlik considers that evil, according to Shevchenko, is a spontaneous manifestation of "human evilness,"

Shevchenkiv svit 3 (2010): 64-65.

Tetiana Bovsunivska, "Mnemonichnyi pratekst Tarasa Shevchenka [Mnemonic Pretext of Taras Shevchenko]," Shevchenkoznavchi studii 11 (2008): 10.

Yurii Barabash, Taras Shevchenko: imperatyv Ukrainy [Taras Shevchenko: The Imperative of Ukraine] (Kyiv: Vydavnychyi dim "Kyievo-Mohylianska Akademiia," 2004).

Antonina Hurbanska, “Taras Shevchenko i Hryhorii Skovoroda: perehuk ekzystentsiinykh vymiriv tvorchosti [Taras Shevchenko and Hryhorii Skovoroda: The Interchange of Existential Dimensions in their Works]," Shevchenkoznavchi studii 18 (2014): 280-86. Oksana Zabuzhko, Shevchenkiv mif Ukrainy. Sproba filosofskoho analizu [Shevchenko's Myth of Ukraine: An Attempt at a Philosophical Analysis] (Kyiv: Abrys, 1997). Tetiana Meizerska, Slovo Shevchenka: mif, metafora, istoriia [Shevchenko's Word: Myth, Metaphor, History] (Odessa: Astroprint, 1996). 
envy, transforming earthly "heaven" to hell, the exhibitions of human insatiability and hypocrisy. ${ }^{35}$ If we follow the poet's thought, we will come to the conclusion that people are the reason for unjust relations, not vice versa.

Shevchenko's thoughts concerning the interrelations of the reasons for evil and human suffering are close to the considerations of the theologist Carlos Valverde:

we, people, are smart beings. Though in a number of life situations we behave like irrational animals. Moreover, we use our mind and freedom for exasperating instincts, bringing disharmony to life and showing unseen cruelty to ourselves and to other people. We must be in concord with others; we cannot live without each other, because only together, with solidarity and love we have the possibility for self-realization. But interpersonal relations are practically unjust, violent, hostile, ill. ${ }^{36}$

Similar thoughts of irrationality and disharmony form the basis of Shevchenko's poem "Moskaleva krynytsia" (The Well of the Muscovite). Thus, Leonid Pliushch considers that the introduction of the "embodiment" of evil to the poem allowed Shevchenko to set the problem of evil in acute, moral and religion form, thereby introducing the issue of the breaking of the circle of evil. Pliushch differentiates between two sides in the image of the main character, the above-mentioned social evil, generated by the imperial system of the state and the psychological problem of the lapse from virtue and possibilities to avoid it. This second aspect is analyzed by Pliushch in detail:

in prison, Shevchenko faced the most odious variants of "amphibians." Shevchenko grounded and resolved the problem of the interrelations of social and individual evil in more realistic ways. From the evil of "avengers" he moved on to the evil of egoists, searching there for the roots of the evil of avengers. That is why avengers and repentant robbers are seen together with absolute criminals, with no social explanations of the reasons for their actions, and the righteous, who are more realistic in a psychological way than the protagonist of "Tryzna" (The Wake). ${ }^{37}$

It is evident that Shevchenko did not always treat the displays of evil or injustice with obedience and humbleness. He often appealed to God, demanding for an answer as in this excerpt from "The Half-Wit":

35 Nakhlik, Dolia, 334.

36 Carlos Valverde, Filosofskaia antropologiia, trans. H. Vdovina (Moscow: Khristianskaia Rossiia, 2000), 229 . 
And as for You, All-Seeing Eye!

As You looked down, did You not spy

How throngs of saints in chains they drove

Into Siberia's frozen wastes,

How tortured them 'mid ice and snow,

And crucified! You did not know?

On all those doing You could gaze

And not be blinded?! Eye, O Eye!

You don't see deep, though look from high!

You sleep in icon... ${ }^{38}$

However, reproaching and blaming God, in his late lyrics Shevchenko passed over to desperate and dramatic God-searches, depicting pain and despair:

There are no words

In far-off captivity!

There are no words, no tears,

No nothing.

You don't even have great God

Around you! ("In Captivity I Count the Days and Nights”). ${ }^{39}$

In the abovementioned examples, Shevchenko has an imaginary conversation with God, the dialogue being mainly egocentric, especially in prison. Nevertheless, theocentric motives prevail in the poems "Psalmy Davydovi" (The Psalms of David), "Podrazhanie 11 Psalmu" (The Imitation of Psalm 11), and the three versions of "Molytva" (Prayer). It is evident that after numerous sufferings (arrest, exile, soldiering, unsuccessful engagement), Shevchenko not only changed his hostile attitude to God present in his early works, but demonstrated a reconsideration of the fact that the path of suffering led to God, it made one reconsider one's mission:

Let be what will be.

Whether to flow on or wander,

At least I'll be forced to crucify myself!

But I'll quietly embroider

These white pages anyway ("In Captivity I Count the Days and Nights"). ${ }^{40}$

Similar ideas are seen in Shevchenko's works, in which characters, having experienced pain, evil, and suffering, do not blaspheme or seek knives or other weapons, they choose the path of humbleness, penance, and martyrdom. The characters of the 
poems "Naimychka" (The Servant Woman), "Vidma” (The Witch), "Kniazhna” (The Princess), "Chernets" (The Monk), "Varnak" (The Convict), "Moskaleva krynytsia” (The Well of the Muscovite), etc. find the individual path of salvation in God. In the poem "Naimychka" a young woman, Hanna, does not only aim at atoning for her sins by praying during her pilgrimage to Kyiv but, having experienced pains and sufferings because of abandoning her own child, she prays for a good destiny for her son; she cares about his health and future family happiness:

And some kopeks eight she saved.

At the shrine of John the Martyr

In the ancient Kiev caves

Hannah bought a cap for Marko

So his head should never ache;

At St. Barbara's shrine she bought

Marko's wife a ring to wear.

Then she prayed to the saint once more,

Crossed herself, and home repaired. ${ }^{41}$

In his old age, after a tempestuous youth in military campaigns, in battles against oppressors, Cossack Semen Palii, in the poem “Chernets," finds himself in a monastery. But during bloody rebellions, in sufferings, and in exile, the hero of the poem continues to love "his Ukraine." Having become a monk, he chooses the path to God, becoming a humble penitent:

To Matins calls the great bell... Startled,

Himself he crosses, takes his plain

Black beads and heavy staff, then, partly

Still wrapt in thought, sighs yet again,

Puts on his cowl, and, heavy-hearted,

Limps off to pray for the Ukraine. ${ }^{42}$

In these works, according to Yevhen Nakhlik,

it is important for the poet to show that the Christian idea is real, that among the "humiliated" lowest layers of society there are people who stoically resist evil by being true Christians - and he shows them as an example for others. Evil is not imbued with sense and doesn't receive any philosophical justification; instead, those who have met evil and have not become embittered, who went through sufferings to individual salvation in God are glorified. ${ }^{43}$

41 Shevchenko, Selected Works, 163.

42 Shevchenko, Selected Works, 212. 


\section{Conclusion}

On the basis of the abovementioned examples, a conclusion can be made that the autobiographical experience of Shevchenko is closely connected with the existential component of his artistic thinking. Because of personal suffering, the poet becomes more sensitive concerning the questions of evil and theodicy, as the world view of the poet is located within the framework of a Christological model. This strategy by Shevchenko demonstrates an exclusively personal character of the phenomenon of suffering, attesting again to the uniqueness of every person. Suffering by the characters is closely connected with religiousness; following the course of events of the poems, one may assume that the phenomenon of suffering becomes the key factor for converting to faith. Shevchenko solves the problem of evil connected with phenomenology by utilizing the ethics of the Bible, and, aside from the early period, his works gravitate to appeals for the truth and revenge, punishment, and physical violence against "the evil-makers," according to Old Testament dogma. The period of exile and works after it are characterized by a change of mood, which aligns with the New Testament commandment to not reply to evil. The artistic embodiment of theodicy in the works of Shevchenko is reinforced by personal experience, which reveals the postulate of Christodicy in his beliefs. The reception of the Byzantine tradition of Bible exegetics, based on the concept of sin in the questions of theodicy, is manifested in Shevchenko's works on the level of the main postulate of the Eastern patristics of the sinfulness of the human being as the cause of evil. It is important to differentiate the social nature of sin, a tradition which was founded by the Old Ukrainian thinker Inokentii Gizel, and found its artistic continuation in the poetic heritage of Taras Shevchenko.

\section{Bibliography}

Abramovych, Dmytro. Kyievo-Pecherskyi Pateryk [Kyivan Cave Patericon]. Kyiv: Chas, 1991.

Barabash, Yurii. Taras Shevchenko: imperatyv Ukrainy [Taras Shevchenko: The Imperative of Ukraine ]. Kyiv: Vydavnychyi dim "Kyievo-Mohylianska Akademiia," 2004.

Bovsunivska, Tetiana. "Mnemonichnyi pratekst Tarasa Shevchenka [Mnemonic Pretext of Taras Shevchenko]." Shevchenkoznavchi studii 11 (2008): 7-12.

Buchynskyi, Dmytro. Khrystyiansko-filosofska dumka Tarasa H. Shevchenka [Taras Shevchenko's Christian-Philosophical Conception]. Madrid; London: Soiuz ukraintsiv u Velykii Brytanii, 1962.

Dovha, Larysa. "Sotsialna utopiia Inokentiia Gizelia [Inokentii Gizel's Social Utopia]." In Ukraina XVII stolittia: suspilstvo, filosofiia, kultura, edited by Larysa Dovha and Nataliia Yakovenko, 221-38. Kyiv: Krytyka, 2005.

Dziuba, Ivan. "Boh. Relihiia. Tserkva u tvorchosti Tarasa Shevchenka [God. Religion. Church in Taras Shevchenko's Writings]." Taras Shevchenko i narodna kultura 1 (2004): 150-69. 
Gizel, Inokentii. Vybrani tvory $v 3$ tomakh [Selected Works in 3 Volumes]. Vol. 1. Kyiv: Svichado, 2009.

Grabowicz, George. Shevchenko, yakoho ne znaiemo [Shevchenko That is Unknown]. Kyiv: Krytyka, 2000.

Hick, John. Evil and God of Love. Cleveland: Fount Paperbacks Collins, 1978.

Horskyi, Vilen. Narysy z istorii filosofskoi kultury Kyivskoi Rusi (seredyna XII-seredyna XIII stolit) [The Essays of Kyivska Rus's Philosophical Culture (Middle of the 12th to the Middle of the 13th Centuries]. Kyiv: Naukova dumka, 1994.

Honcharuk, Tetiana. "Postat Tarasa Shevchenka u filosofskykh intentsiiakh Oleksandra Kulchytskoho [The Figure of Taras Shevchenko in the Philosophical Intentions of Oleksandr Kulchytskyi]." Mandrivets 6 (2008): 8o-83.

Howard-Snyder, Daniel. The Evidential Argument from Evil. Bloomington: Indiana University Press, 1996.

Hurbanska, Antonina. "Taras Shevchenko i Hryhorii Skovoroda:perehuk ekzystentsiinykh vymiriv tvorchosti [Taras Shevchenko and Hryhorii Skovoroda: The Interchange of the Existential Dimensions in their Works]." Shevchenkoznavchi studii 18 (2014): $280-86$.

Meizerska, Tetiana. Slovo Shevchenka: mif, metafora, istoriia [Shevchenko's Word: Myth, Metaphor, History]. Odessa: Astroprint, 1996.

Mokry, Włodzimierz. Literatura i myśl filozoficzno-religïna ukraińskiego romantyzmu: Szewczenko, Kostomarow, Szaszkiewicz. Kraków: Uniwersytet Jagielloński, 1996.

Nakhlik, Yevhen. Dolia - Los_Sudba:Shevchenko ipolski ta rosiiski romantyky [FateLos - Destiny: Taras Shevchenko and Polish and Russian Romantics]. Lviv: Svit, 2003.

Pakharenko, Volodymyr. “'Oi try shliakhy shyrokii...' (Pro Shevchenkove bachennia borotby zi zlom) ['Oh Three Roads Wide...' (About Shevchenko's Vision of the Battle against Evil)]." Shevchenkiv svit 3 (2010): 44-66.

Perets, Vladimir. Issledovaniia i materialy po istorii ukrainskoi literatury XVI-XVIII vekov. Moscow; Leningrad: Izdatelstvo Akademii nauk USSR, 1962.

Peterson, Michael L. The Problem of Evil. Indiana: University of Notre Dame Press, 1992. Pliushch, Leonid. Ekzod Tarasa Shevchenka [Taras Shevchenko's Exodus]. Kyiv: Fakt, 2001.

Popper, Karl R. The Open Society and its Enemies. Vol. 1. London: Routledge, 1962.

Shevchenko, Taras. Povne zibrannia tvoriv u 12 tomakh [Complete Works in 12 Volumes]. Vol. 5. Kyiv: Naukova dumka, 2003.

Shevchenko, Taras. Selected Works, Poetry and Prose. Translated by Irina Zheleznova. Moscow: Progress Publishers, 1979.

Stepovyk, Dmytro. Nasliduiuchy Khrysta:viruiuchyi u Boga Taras Shevchenko [Following the Example of Christ: Believer in God Taras Shevchenko]. Kyiv: Vydavnytstvo im. Oleny Telihy, 2013.

Valverde, Carlos. Filosofskaia antropologiia. Translated by H. Vdovina. Moscow: Khristianskaia Rossiia, 2000. 
Vasylii Velykyi. Moralno-asketychni tvory [Ethic and Ascetic Works]. Lviv: Svichado, 2006. Yaremenko, Vasyl. "'Liudei i ... ne prokliav!' (Do problemy Shevchenkovoho traktuvannia teodytsei) ['The People but ... He didn't Damn!' (To the Problem of Shevchenko's Interpretation of Evil]." Kyivska starovyna 2 (2005): 108-17.

Zlatoust, Ioann. Polnoe sobranie tvoreniiv 12 tomakh. Vol. 3. Pochaev: Sviato-Uspenskaia Pochaevskaia Lavra, 2005.

Zabuzhko, Oksana. Shevchenkiv mif Ukrainy. Sproba filosofskoho analizu [Shevchenko's Myth of Ukraine: An Attempt at a Philosophical Analysis]. Kyiv: Abrys, 1997.

\section{(2)}

Olha Bihun holds a Doctorate in Philology and is a professor at the Department of French Philology at Vasyl Stefanyk Precarpathian National University. She is the author of over 80 articles and 2 monographs. Her academic interests include a study of the Byzantine tradition in Shevchenko's writings and Ukrainian works of ancient times, translation theory, French literature of the late 19th - early 2oth centuries, and the methodology of teaching French. 